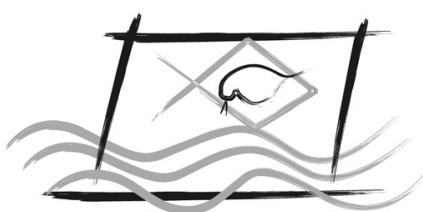

ECOTOX - BRASIL

\title{
Piscine micronucleus test and the comet assay reveal genotoxic effects of Atrazine herbicide in the neotropical fish Rhamdia quelen
}

\author{
L.D.S. Piancini; G.S. Santos; F.H. Tincani; M.M. Cestari \\ Universidade Federal do Paraná, Departamento de Genética, Jardim das Américas, Centro Politécnico - Caixa Postal: 19071, \\ CEP 81531-990, Curitiba, PR - Brazil
}

(Received November 18, 2014; Accept August 25, 2015)

\begin{abstract}
Atrazine (ATZ) is an herbicide extensively used around the world to kill weeds. Due to its applicability and benefits in farming, ATZ can easily reach the aquatic ecosystems and, therefore, represent risks for aquatic biota and human populations. The aim of this study was to evaluate the genotoxic effects of ATZ on Rhamdia quelen through the piscine micronucleus test (MNT) and the comet assay in erythrocytes (ECA) and gill cells (GCA), at three different concentrations (2, 10, and $100 \mu \mathrm{g}$ $\mathrm{L}^{-1}$ ) in static (SB) and semi-static bioassays (SSB) during 96 hours. In the SB, we observed an increased frequency of nuclear morphological abnormalities at all concentrations and a dose-dependent effect of ATZ on DNA through the ECA. There was no difference among treatments in gills. In the SSB there was no significant difference in MNT, but the ECA showed an increase of DNA breakages at $10 \mu \mathrm{g} \mathrm{L}^{-1}$ treatment. GCA showed higher DNA damage on fish exposed to 2 and $100 \mu \mathrm{g} \mathrm{L}{ }^{-1}$. Our results show a trend to dose-dependent genotoxic effect of ATZ, which causes damage to the DNA of Rhamdia quelen even in a concentration considered safe by regulatory agencies.
\end{abstract}

Keywords: ecotoxicology, erythrocytes, genotoxicity, gills, pesticide, silver catfish.

\section{INTRODUCTION}

Herbicides are biocides used in agriculture to control unwanted plants, i.e. poisons used to exterminate competing weeds and pests (Grisolia, 2005; Bolognesi, 2003). These herbicides can unintentionally or indirectly reach aquatic ecosystems, causing harmful effects to the environment and human populations (Cavalcante et al., 2008).

Atrazine (ATZ) is a selective triazinic herbicide, used since the early 1950s in crops like corn, sugarcane, sorghum, soybeans, and some other broad-leaf crops (Azevedo et al., 2004). ATZ has a broad potential for contamination in different environmental compartments due its characteristics, such as: high potential for leaching and runoff, high persistence in soils, slow hydrolysis, low solubility in water and moderate absorption to organic matter (Bolognesi, 2003). Studies conducted in the past two decades, showed that ATZ is one of the most frequently detected herbicides in streams and rivers near agricultural areas (Comber, 1999; Fischerscherl et al., 1991; Vryzas et al., 2011).

ATZ is a common contaminant of aquatic systems, having concentrations ranging from 0.2 to $20 \mu \mathrm{g} \mathrm{L}^{-1}$ been detected in runoff waters (Selim, 2003), however, in streams adjacent to crops, this value can reach as high as $1000 \mu \mathrm{g} \mathrm{L}^{-1}$ (Graymore et al., 2001). ATZ was banned in the European Union in 2004, as well as any products containing this active ingredient. This restriction arose mainly because ATZ and its degradation byproducts exceeded $0.1 \mu \mathrm{g} \mathrm{L}^{-1}$ in the groundwater of different places and, therefore, the continuous use of this herbicide could impair the recovery of groundwater quality (EU, 2004). The Brazilian National Council for the Environment (CONAMA) limited the highest acceptable ATZ concentration in freshwater to $2 \mu \mathrm{g} \mathrm{L}^{-1}$ for biota conservation (BRASIL, 2005), however ATZ concentrations higher than

*Corresponding author: Laercio Dante Stein Piancini; e-mail: laerciopiancini@gmail.com 
this have been found in the surface water of rivers next to crop fields in Brazil (Armas et al., 2007).

In the last two decades, several studies have raised doubts about the safety of ATZ on different organisms. Low concentrations of ATZ caused hermaphroditism in amphibians (Hayes et al., 2002a, 2003; Hayes et al., 2002b), and adverse effects on fish reproduction (Salaberria et al., 2009; Tillitt et al., 2010). Activation of the cytochrome P450 enzymatic complex, involved in the process of ATZ detoxification, was observed in Danio rerio (Dong et al., 2009; Jin et al., 2010). In addition, changes in the expression of enzymes involved in the detoxification process were also observed in carp (Cericato et al., 2009; Xing et al., 2010a; Xing et al., 2010b). Genotoxic effects were reported in Piaractus mesopotamicus (Moron et al., 2006), Channa punctatus (Nwani et al., 2011), and Oreochromis niloticus (Ventura et al., 2008).

Understanding the mechanisms by which chemicals affects the health of the biota is fundamental to accurately assess the transient impacts over the environment. In that sense, knowing the physical and chemical characteristics of a given substance is important to choose an adequate type of bioassay, which can be conducted in static (SB) or semi-static (SSB) conditions (Aragão\& Araújo, 2006). In the static model, there is no renewal of the test-solution during the experimental interval, i.e. the organisms are exposed to the same solution from the beginning to the end of the experiment. On the other hand, in the semi-static model, the experiment is performed with partial exchange and reposition of the test-solution in pre-determined time intervals (Aragão \& Araújo, 2006).

The piscine micronucleus test has been used as one of the main tools in the assessment of clastogenic and aneugenic potential of different compounds in the aquatic environment. Several studies have shown increase in the frequency of micronucleus and other morphological abnormalities in erythrocytes of fish exposed to different pollutants in bioassays (Ventura et al., 2008; Ghisi et al., 2011; Grisolia \& Cordeiro, 2000; Ramsdorf et al., 2009a), as well as in field studies (Ergene et al., 2007; De Flora et al., 1993; Katsumiti et al., 2009).

The single cell gel electrophoresis, or comet assay, is a technique capable to assess DNA breaks in virtually any soft tissue. This test has mostly been applied to erythrocytes, because these cells types can be easily sampled and cell dissociation is not needed (Belpaeme et al., 1996). In addition, gills have also been used (Deventer, 1996), mainly because of their continuous contact with the water.

This study evaluated the genotoxic potencial of ATZ to the neotropical fish Rhamdia quelen (silver catfish) exposed to environmentally relevant concentrations of the herbicide, in static and semi-static bioassays through the piscine micronucleus test and comet assay of blood and gill cells.

\section{MATERIAL AND METHODS}

Atrazine (CAS 1912-24-9, Sigma Aldrich, USA) concentrations were obtained from a stock solution prepared in distilled water at $0.032 \mathrm{~g} \mathrm{~L}^{-1}$.

\section{Experimental Design}

Specimens of silver catfish $(23.04 \pm 3.07 \mathrm{~g})$ were acquired in a fish farm. The fish were acclimatized for 30 days in tanks of $250 \mathrm{~L}$ with filtered water, constant aeration, average temperature of $26^{\circ} \mathrm{C}$, photoperiod of 12 hours, and daily feeding. A week before the beginning of the experiment, eighty fish were randomly assigned to four aquaria of $108 \mathrm{~L}$ ( 20 specimens per aquarium) in conditions similar to the tanks (water, aeration, temperature, etc). One aquarium was assigned as a negative control group (NC) and the other three as treatment groups, for each type of bioassay (SB and SSB). Fishes were exposed to atrazine at the following nominal concentrations: $2 \mu \mathrm{g} \mathrm{L}^{-1}$, the maximum allowed in Brazilian waters by CONAMA resolution 357/2005 (BRASIL 2005); $10 \mu \mathrm{g} \mathrm{L}^{-1}$, an intermediate concentration similar to that applied into crop fields; and $100 \mu \mathrm{g}$ $\mathrm{L}^{-1}$, a four times higher concentration than that applied in crop fields (Ventura et al., 2008).

Concerning the SB, there was no renewal of water during the period of 96 hours of exposure. On the other hand, in the $\mathrm{SSB}, 36 \mathrm{~L}$ of water was removed from each aquarium and replaced by a new $36 \mathrm{~L}$ test-solution every 24 hours.

\section{Piscine Micronucleus Test}

The piscine micronucleus test (MNT) was performed according to the technique described by Hooftman \& De Raat (1982). For each fish, 2.000 erythrocytes were examined under $1.000 \times$ magnification and scored for the presence of both typical micronuclei and nuclear morphological abnormalities manifested as changes in the normal elliptical shape of the nuclei. The frequency of micronuclei and nuclear morphological abnormalities were observed according to Carrasco et al., (1990), quantified and named as MNT (Ferraro et al., 2004; Katsumiti et al., 2009; Ramsdorf et al., 2009a).

\section{Single Cell Gel Electrophoresis - Comet Assay}

The comet assay with peripheral blood (erythrocytes; ECA) was performed according to Speit \& Hartmann (1999), modified by Cestari et al. (2004) and Ferraro et al. (2004). For the gill comet assay (GCA), the first gill arch of the right side of each fish was excised and placed in a petri dish and washed in phosphate buffer solution (PBS, pH 7.4). The bone arch was removed with a scalpel and only the lamellae were transferred to a microtube containing $0.5 \mathrm{~mL}$ of fetal bovine serum (FBS). The lamellae were mechanically homogenized at 1,500 rpm (homogenizer Tecnal - TE-103).Ten microliters aliquot was taken from each diluted sample and embedded in $120 \mu \mathrm{L}$ of low- melting-point agarose (Invitrogen, 0.5\%). The following steps were conducted according to Speit \& Hartmann (1999).

One hundred nucleoids were analyzed for each fish (Collins et al., 1997) according to the visual classification based on the migration of DNA fragments from the nucleus. The results were categorized into classes according to Ramsdorf et al. (2009b). 


\section{Statistical Analysis}

Since the data obtained from the biomarker analysis are categorical, non-parametric statistical approaches were chosen. The Kruskal-Wallis test was used to compare negative control and contaminated treatments for the evaluation of micronucleus frequency and other nuclear morphological abnormalities, as well as the comet assay for each tissue separately. The Wilcoxon test was used to compare the ECA and GCA between the same groups, while the Mann-Whitney test was performed to compare the different bioassays. Results with $\mathrm{p}<0.05$ were considered statistically significant.

\section{RESULTS}

There was no animal death in the 96 hours of exposure to ATZ in either experiments (SB and SSB).

\section{Static Bioassay (SB)}

The frequency of MNT increased in all treatments when compared to the $\mathrm{NC}$, while no significant differences were observed among treatments (Fig. 1).

In regard to the ECA, specimens exposed to 10 and 100 $\mu \mathrm{g} \mathrm{L}^{-1}$ showed higher DNA damage in comparison to the NC (Fig. 2, white bars). The GCA, in turn, presented less DNA damage in the concentration of $2 \mu \mathrm{g} \mathrm{L}^{-1}$ when compared to the NC (Fig. 2, striped bars). These results from ECE suggest a dose-dependent response mechanism of $R$. quelen to ATZ.

The results of the comet assay in different tissues showed a tendency to higher DNA damage in blood cells, what was significantly seen in the group of $100 \mu \mathrm{g} \mathrm{L}^{-1}$. The $\mathrm{NC}$, however, presented higher damage to the DNA in the GCA (Fig. 2).

\section{Semi-static Bioassay (SSB)}

The MNT presented significant differences between the $\mathrm{NC}$ and the concentrations of $2 \mu \mathrm{g} \mathrm{L}^{-1}$ and $10 \mu \mathrm{g} \mathrm{L}-1$ (Fig. 1).

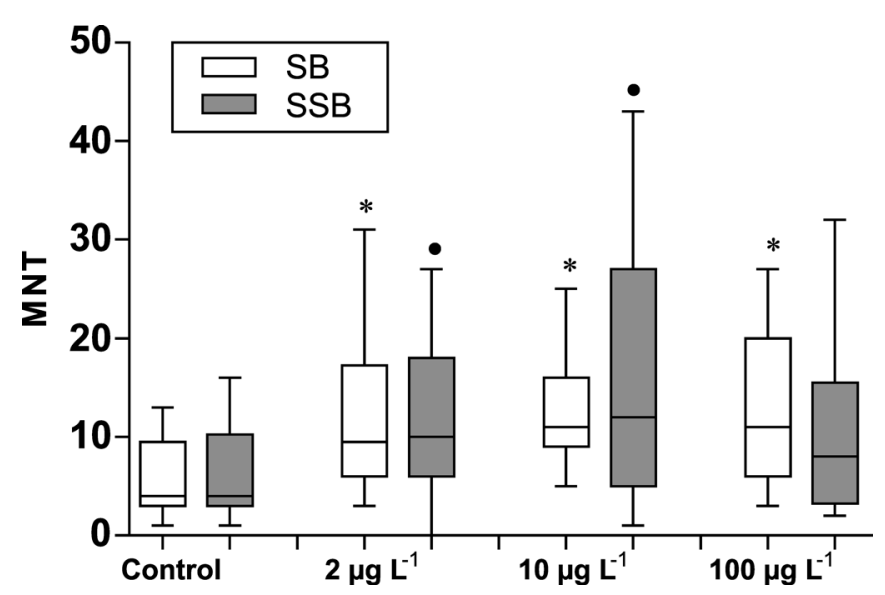

Figure 1 -Frequency of MNT between groups for the SB (white) and SSB (grey) bioassays. * represents statistical significance of treatments in comparison to the $\mathrm{NC}$ for the $\mathrm{SB}$. • represents statistical significance of treatments in comparison to the $\mathrm{NC}$ for the SSB.

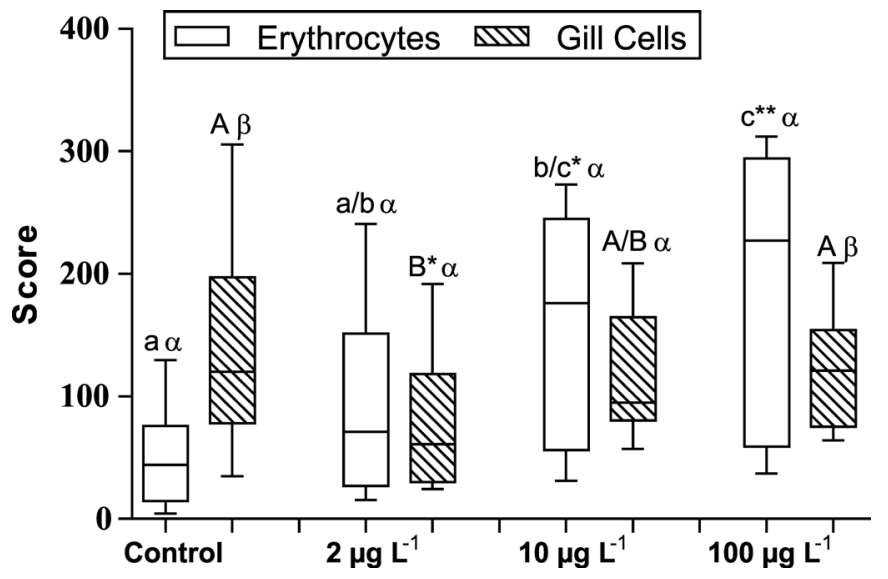

Figure2- Scores of the comet assay in the SB. Greek characters represent statistical significance between tissues. Lowercase Latin characters represent the differences in the ECA and uppercase Latin characters represent the differences in the GCA. * represents statistical significance of treatments in comparison to the $\mathrm{NC}$.

In this experiment, we could not perform the ECA analysis of the slides of the $100 \mu \mathrm{g} \mathrm{L}-1$ treatment, due to technical problems that occurred during the execution of the technique. However, for the ECA, the treatment of $10 \mu \mathrm{g} \mathrm{L}^{-1}$ of ATZ presented higher DNA damage when compared to the NC (Fig. 3 , white bars), while the GCA presented higher DNA damage in the concentrations of 2 and $100 \mu \mathrm{g} \mathrm{L}^{-1}$ when compared to the NC and lower DNA damage in the concentration of $10 \mu \mathrm{g}$ $\mathrm{L}^{-1}$ also in comparison to the NC. (Fig. 3, striped bars).

In regard to the comparisons between different tissues, there were higher damage to the DNA of gill cells in the NC and $2 \mu \mathrm{g} \mathrm{L}^{-1}$ groups (Fig. 3).

\section{Inter Assay Comparison (SB $x$ SSB)}

Table 1 shows the comparison among bioassays. In the $\mathrm{SSB}$, the damage in the DNA of gill cells was higher in the concentrations of 2 and $100 \mu \mathrm{g} \mathrm{L}^{-1}$ when compared to the

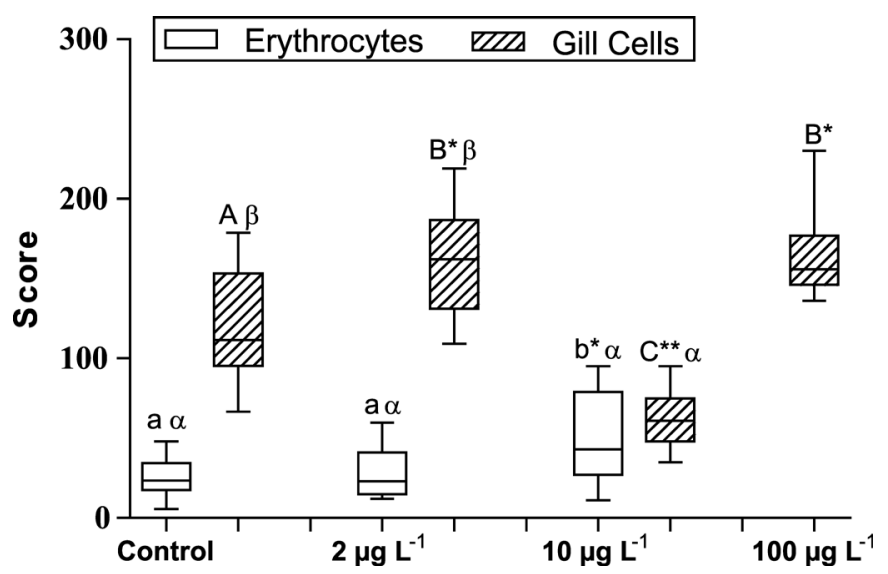

Figure3 - Scores of the comet assay in the SSB. Greek characters represent statistical significance between tissues. Lowercase Latin characters represent the differences in the ECA and uppercase Latin characters represent the differences in the GCA. * represents statistical significance of treatments in comparison to the $\mathrm{NC}$. 
Table 1 - Median of scores in the SB and SSB

\begin{tabular}{|c|c|c|c|}
\hline \multicolumn{2}{|c|}{ SB } & \multicolumn{2}{|c|}{ SSB } \\
\hline Median & Q1-Q3 & Median & Q1-Q3 \\
\hline
\end{tabular}

\begin{tabular}{lrrrr}
\hline Gills & & & & \\
Control & 120.00 & $78.00-197.00$ & 111.50 & $95.25-153.30$ \\
$2 \mu \mathrm{g} \mathrm{L}^{-1 *}$ & 61.00 & $30.25-61.00$ & 162.00 & $131.00-186.50$ \\
$10 \mu \mathrm{g} \mathrm{L}^{-1 * *}$ & 95.00 & $80.50-164.80$ & 61.00 & $48.00-75.00$ \\
$100 \mu \mathrm{g} \mathrm{L}^{-1 *}$ & 121.00 & $75.00-154.00$ & 156.00 & $146.00-177.00$ \\
Erythrocytes & & & & \\
Control & 44.00 & $14.50-76.25$ & 23.50 & $17.50-34.25$ \\
$2 \mu \mathrm{g} \mathrm{L}^{-1 *}$ & 71.00 & $26.75-151.50$ & 23.00 & $15.00-41.00$ \\
$10 \mu \mathrm{L}^{-1 * *}$ & 176.00 & $56.25-244.80$ & 43.00 & $27.00-79.00$ \\
$100 \mu \mathrm{g} \mathrm{L} \mathrm{L}^{-1}$ & 229.50 & $63.50-293.80$ & - & - \\
\hline
\end{tabular}

* $\mathrm{p}<0.05$ statistically significant in comparison to the NC. ${ }^{* *} \mathrm{p}<0.01$ statistically significant in comparison to the NC. Q1: Quartile one; Q3: Quartile 3.

same concentrations of the SB experiment, and it was lower in the concentration of $10 \mu \mathrm{g} \mathrm{L}^{-1}$ for the same comparison. The erythrocytes of fish from the SB, in turn, had more DNA damage from those of the SSB.

\section{DISCUSSION}

The production of data on genotoxic effects of contaminants is a well-established approach in the literature used to evaluate acute and chronic exposure of aquatic organisms. The negative effects of ATZ in the aquatic environment and its consequences to biota has been thoroughly described (Moron et al., 2006; Dong et al., 2009; Nwani et al., 2011; Salaberria et al., 2009; Tillitt et al., 2010; Ventura et al., 2008) however, despite its banishment in the European Union, ATZ is still a widely used herbicide in several crops around the world (Nwani et al., 2011). Therefore, due to the risk that ATZ represents to wild life and human populations, further investigations of its effects are required. Regarding this work, our data on genotoxic effects of ATZ provided many evidences in agreement with the literature and also some results that deserve further discussion.

The analysis of MNT showed that the groups treated with ATZ presented more alterations when compared to the control group. Increase in the frequency of morphological nuclear abnormalities induced by acute exposure to ATZ has also been reported by some authors in different species of fish (Nwani et al., 2011; Ventura et al., 2008; Moron et al., 2006). In addition, our results demonstrated that ATZ has clastogenic effects on fish erythrocytes, even at the maximum concentrations allowed by regulatory agencies (Brazilian legislation (2 $\left.\mu \mathrm{g} \mathrm{L}^{-1}\right)$ (BRASIL, 2005); US Environmental Protection Agency (5 $\left.\mu \mathrm{g} \mathrm{L}^{-1}\right)$ (USEPA, 2006)). This latter finding, in special, is of great concern for the society, leading to more rigorous studies over the limits proposed by these regulatory agencies.

Different types of DNA damage arise in cells as singlestrand breaks, double-strand breaks or formation of DNA adducts (Mitchelmore \& Chipman, 1998), resulting from the interaction of herbicides with the DNA. These adverse effects, especially DNA breakages, have been noticed to be dose-dependent for ATZ (Nwani et al., 2011; Ventura et al., 2008). In this study we notice a trend for this dose-dependent effect of ATZ in ECA of the SB $\left(10 \mu \mathrm{g} \mathrm{L}^{-1}\right.$ and $\left.100 \mu \mathrm{g} \mathrm{L}^{-1}\right)$. In the lowest concentration $\left(2 \mu \mathrm{g} \mathrm{L}^{-1}\right)$ no significant difference was observed, however, the median score of this group was higher than the median of the NC (Table 1). Despite nonsignificant, this data may be biologically relevant when considered in conjunction with the MNT which shows that ATZ can cause morphological nuclear abnormalities to the erythrocytes in environmentally meaningful concentrations, such as those found in ground and surface water (Fischerscherl et al., 1991; Vryzas et al., 2011). Nonetheless, new testing in concentrations close to this should be conducted since the results of the ECA indicates a possible genotoxic effect of ATZ, that is in agreement with the MNT findings in this study.

No evidence of genotoxicity through the GCA in the SB experiment was observed in this study. Ghisi et al. (2011) found similar results for $R$. quelen exposed to Fipronil. They observed higher frequency of MNT in erythrocytes in the concentrations of 0.10 and $0.23 \mu \mathrm{g} \mathrm{L}^{-1}$, but did not observed increase in the DNA damage in gill cells. They also evaluated the gill through histopathological methods and did not find significant differences between the NC and treatments. Despite significant only in the $100 \mu \mathrm{g} \mathrm{L}^{-1}$ treatment, we observed an increased score of the ECA when compared to the GCA, what might as well corroborate the situation described above, since the ATZ that was briefly in contact with the gills might have been carried to the fish bloodstream, where it can act as a jeopardizing agent to the erythrocytes.

Concerning the ECA in the SSB bioassay, we observed an increased DNA damage in the $10 \mu \mathrm{g} \mathrm{\textrm {L } ^ { - 1 }}$ treatment. Unfortunately, the loss of the $100 \mu \mathrm{g} \mathrm{L^{-1 }}$ group does not allow us to infer about the existence of a dose-dependent genotoxic effect of ATZ in this experiment. Genotoxicity of ATZ through the GCA of the SSB experiment was observed in the concentrations of 2 and $100 \mu \mathrm{g} \mathrm{L}^{-1}$, but not in the 10 $\mu \mathrm{g} \mathrm{L}^{-1}$. Nwani et al. (2011) tested the effects of ATZ (4.24, 5.30 , and $8.48 \mathrm{mg} \mathrm{L}^{-1}$ ) on Channa punctatus in a chronic exposure experiment during 35 days through the MNT, ECA, and GCA. They found a dose-dependent effect of ATZ on this species, and also that genotoxic effects reached a peak period, followed by a non-linear decrease. The highest formation rate of micronuclei was found at seven days of exposure, and the 
highest rate of DNA breakage in the comet assay was found at five days of exposure, both for gills and erythrocytes.

In general, we can conclude that ATZ cause genotoxic effects in R. quelen. We found positive results with the piscine micronucleus test and comet assay, especially in erythrocytes, at environmentally meaningful concentrations. The dosedependent effects of this contaminant were also found by other authors (Jin et al., 2010; Nwani et al., 2011; Ventura et al., 2008), and confirmed by our results through the ECA in the SB. We also conclude that the erythrocytes are more sensitive to the genotoxic effects of ATZ than the gills. We encourage other studies to better investigate the mechanisms involving the kinetics and dynamics of xenobiotics in different experimental designs. In addition, it is clear that the piscine micronucleus test and comet assay are valid methodologies for the assessment of aquatic genotoxicity of herbicides in neotropical fish species as it was shown in Rhamdia quelen, demonstrating that this species is sensitive to genotoxic assays. Finally, since we found alarming results regarding the limits of ATZ proposed by regulatory agencies, we recommend the conduction of more studies over these limits in order to accurately certify the environmental thresholds of ATZ to levels that will not impact the ecosystem.

\section{ACKNOWLEDGMENTS}

The authors thank CNPq (Conselho Nacional de Desenvolvimento Científico e Tecnológico) and Aquatóxi group. This research was supported by Coordenação de Aperfeiçoamento de Pessoal de Nível Superior (CAPES) and Plano de Reestruturação das Universidades (REUNI). We also thank Dr. Mocelin, G. for his contribution to this paper.

\section{REFERENCES}

ARAGÃO, M.A. \& ARAÚJO, R.P.A. 2006. Métodos de ensaios de toxicidade com organismos aquáticos. In: Zagatto, P.A. \& Bertoletti, E. (eds) Ecotoxicologia Aquática Princípios e Aplicações. Editora Rima, São Carlos, pp 117-147

AZEVEDO, D.D., GERCHON, E. \& DOS REIS, E.O. 2004. Monitoring of pesticides and polycyclic aromatic hydrocarbons in water from Paraiba do Sul River, Brazil. J. Brazil Chem. Soc.,15 (2):292-299. http://dx.doi.org/10.1590/S010350532004000200021

BELPAEME, K., DELBEKE, K., ZHU, L. \& KIRSCHVOLDERS, M. 1996. Cytogenetic studies of PCB77 on brown trout (Salmo trutta fario) using the micronucleus test and the alkaline comet assay. Mutagenesis 11 (5):485-492. http://dx.doi.org/10.1093/ mutage/11.5.485

BOLOGNESI, C.2003. Genotoxicity of pesticides: a review of human biomonitoring studies. Mutat. Res./Rev. Mutat. Res., 543 (3):251-272. http://dx.doi.org/10.1016/S1383-5742(03)00015-2

BRASIL. 2005. Conselho Nacional do Meio Ambiente/Ministério do Meio Ambiente. Resolucão n. 357 de 17 de março de 2005. Disponível em: http://www.mma.gov.br/port/conama/legiabre. cfm?codlegi $=459$.

CARRASCO, K.R., TILBURY, K.L. \& MYERS, M.S. (1990) Assessment of the piscine micronucleus test as an in situ biological indicator of chemical contaminant effects. Can. J.
Fish Aquat. Sci., 47 (11):2123-2136. http//dx.doi.org/10.1139/ f90-237

CAVALCANTE, D.G.S.M., MARTINEZ, C.B.R. \& SOFIA, S.H. 2008. Genotoxic effects of Roundup ${ }^{\circledR}$ on the fish Prochilodus lineatus. Mutat. Res./Genetic Toxicol. Environ. Mutag. 655 (12):41-46. http://dx.doi.org/10.1016/j.mrgentox.2008.06.010

CERICATO, L., NETO, J.G.M., KREUTZ, L.C., QUEVEDO, R.M., DA ROSA, J.G.S., KOAKOSKI, G., CENTENARO, L., POTTKER, E., MARQUEZE, A. \& BARCELLOS, L.J.G. 2009. Responsiveness of the interrenal tissue of Jundiá (Rhamdia quelen) to an in vivo ACTH test following acute exposure to sublethal concentrations of agrichemicals. Comp. Biochem. Phys. C, 149 (3):363-367. http://dx.doi.org/10.1016/j. cbpc.2008.09.002

CESTARI, M.M., LEMOS, P.M.M., RIBEIRO, C.A.D., COSTA, J.R.M.A., PELLETIER, E., FERRARO, M.V.M., MANTOVANI, M.S. \& FENOCCHIO, A.S. 2004. Genetic damage induced by trophic doses of lead in the neotropical fish Hoplias malabaricus (Characiformes, Erythrinidae) as revealed by the comet assay and chromosomal aberrations. Genet. Mol. Biol.,27 (2):270-274. http://dx.doi.org/10.1590/S1415-47572004000200023

COLLINS, A., DUSINSKA, M., FRANKLIN, M., SOMOROVSKA, M., PETROVSKA, H., DUTHIE, S., FILLION, L., PANAYIOTIDIS, M., RASLOVA, K. \& VAUGHAN, N. 1997. Comet assay in human biomonitoring studies: Reliability, validation, and applications. Environ. Mol. Mutagen.,30 (2):139-146. http://dx.doi.org/10.1002/(SICI)10982280(1997)30:2<139::AID-EM6>3.0.CO;2-I

COMBER, S.D.W. 1999. Abiotic persistence of atrazine and simazine in water. Pestic. Science, 55 (7):696-702.

DE FLORA, S., VIGANO, L., D'AGOSTINI, F., CAMOIRANO, A., BAGNASCO, M., BENNICELLI, C., MELODIA, F. \& ARILLO, A. 1993. Multiple genotoxicity biomarkers in fish exposed in situ to polluted river water. Mutat. Res./Genetic Toxicol. Environ. Mutag., 319 (3):167-177. http://dx.doi. org/10.1016/0165-1218(93)90076-P

DEVENTER, K. 1996. Detection of genotoxic effects on cells of liver and gills of $B$-rerio by means of single cell gel electrophoresis. Bull. Environ. Contam. Toxicol., 56 (6):911-918. http//dx.doi. org/10.1007/s001289900132

DONG, X.L., ZHU, L.S., WANG, J.H., WANG, J., XIE, H., HOU, X.X. \& JIA, W.T. 2009. Effects of atrazine on cytochrome P450 enzymes of zebrafish (Danio rerio). Chemosphere 77 (3):404412. http://dx.doi.org/10.1016/j.chemosphere.2009.06.052

ERGENE, S., CAVAS, T., CELIK, A., KOLELI, N. \& AYMAK, C. 2007. Evaluation of river water genotoxicity using the piscine micronucleus test. Environ. Mol. Mutagen., 48 (6):421-429. http://dx.doi.org/10.1002/em.20291

EU. 2004. Concerning the non-inclusion of atrazine in Annex I to Council Directive 91/414/EEC and the withdrawal of authorisations for plant protection products containing this active substance (2004/248/EC). Official Journal of the European Union.

FERRARO, M.V.M., FENOCCHIO, A.S., MANTOVANI, M.S., DE OLIVEIRA RIBEIRO, C. \& CESTARI, M.M. 2004. Mutagenic effects of tributyltin and inorganic lead ( $\mathrm{Pb}$ II) on the fish $H$. malabaricus as evaluated using the comet assay and the piscine micronucleus and chromosome aberration tests. Genet. Mol. Biol., 27:103-107. http://dx.doi.org/10.1590/S141547572004000100017

FISCHERSCHERL, T., VEESER, A., HOFFMANN, R.W., KUHNHAUSER, C., NEGELE, R.D. \& EWRINGMANN, T. 1991. Morphological Effects of Acute and Chronic Atrazine Exposure in Rainbow-Trout (Oncorhynchus-Mykiss). Arch. Environ. Contam. Toxicol., 20 (4):454-461. http://dx.doi. org/10.1007/BF01065833 
GHISI, N.D., RAMSDORF, W.A., FERRARO, M.V.M., DE ALMEIDA, M.I.M., RIBEIRO, C.A.D. \& CESTARI, M.M. 2011. Evaluation of genotoxicity in Rhamdia quelen (Pisces, Siluriformes) after sub-chronic contamination with Fipronil. Environ. Mon. Assess., 180 (1-4):589-599. http://dx.doi. org/10.1007/s10661-010-1807-7

GRAYMORE, M., STAGNITTI, F., ALLISON, G. 2001. Impacts of atrazine in aquatic ecosystems. Environ. Int., 26, 483-495.http:// dx.doi.org/10.1016/S0160-4120(01)00031-9

GRISOLIA, C.K. 2005. Agrotóxicos Mutações, Câncer e Reprodução. Editora da UNB, Brasília.

GRISOLIA, C.K. \& CORDEIRO, C.M.T. 2000.Variability in micronucleus induction with different mutagens applied to several species of fish. Genet. Mol. Biol., 23 (1):235-239. http:// dx.doi.org/10.1590/S1415-47572000000100041

HAYES, T., HASTON, K., TSUI, M., HOANG, A., HAEFFELE, C. \& VONK, A. 2002a. Herbicides: Feminization of male frogs in the wild. Nature. 419 (6910):895-896. http://dx.doi. org/10.1038/419895a

HAYES, T.B., COLLINS, A., LEE, M., MENDOZA, M., NORIEGA, N., STUART, A.A. \& VONK, A. 2002b. Hermaphroditic, demasculinized frogs after exposure to the herbicide atrazine at low ecologically relevant doses. Proc. Nat. Acad. Sci. USA, 99 (8):5476-5480. http://dx.doi.org/10.1073/pnas.082121499

HAYES, T., HASTON, K., TSUI, M., HOANG, A., HAEFFELE, C. \& VONK, A. 2003. Atrazine-induced hermaphroditism at 0.1 $\mathrm{ppb}$ in American leopard frogs (Rana pipiens): Laboratory and field evidence. Environ. Health. Persp.,111 (4):568-575. http:// dx.doi.org/10.1289/ehp.5932

HOOFTMAN, R.N. \& DE RAAT, W.K.1982. Induction of Nuclear Anomalies (Micronuclei) in the Peripheral-Blood Erythrocytes of the Eastern Mudminnow Umbra Pygmaea by Ethyl Methanesulfonate. Mutat. Res., 104 (1-3):147-152. http://dx.doi. org/10.1016/0165-7992(82)90136-1

JIN, Y.X., ZHANG, X.X., SHU, L.J., CHEN, L.F., SUN, L.W., QIAN, H.F., LIU, W.P. \& FU, Z.W. 2010. Oxidative stress response and gene expression with atrazine exposure in adult female zebrafish (Danio rerio). Chemosphere, 78 (7):846-852. http://dx.doi.org/10.1016/j.chemosphere.2009.11.044

KATSUMITI, A., DOMINGOS, F.X.V., AZEVEDO, M., DA SILVA, M., DAMIAN, R., ALMEIDA, M.I., DE ASSIS, H.C.S., CESTARI, M.M., RANDI, M.A. \& RIBEIRO, C.A.O. 2009.An assessment of acute biomarker responses in the demersal catfish Cathorops spixii after the Vicuña Oil Spill in a harbour estuarine area in Southern Brazil. Environ. Mon. Assess., 152 (1):209-222. http://dx.doi.org/10.1007/s10661-008-0309-3

MITCHELMORE, C.L. \& CHIPMAN, J.K. 1998. DNA strand breakage in aquatic organisms and the potential value of the comet assay in environmental monitoring. Mutat. Res., 399 (2):135-147. http://dx.doi.org/10.1016/S0166-445X(97)00064-7

MORON, S., POLEZ, V., ARTONI, R., RIBAS, J. \& TAKAHASHI, H.2006. Estudo de alterações na concentração dos íons plasmáticos e da indução de micronúcleos em Piaractus mesopotamicus exposto ao herbicida atrazina. J. Braz. Soc. Ecotoxicol., 1 (1):2730. http://dx.doi.org/10.5132/jbse.2006.01.006
NWANI, C.D., NAGPURE, N.S., KUMAR, R., KUSHWAHA, B., KUMAR, P. \& LAKRA, W.S. 2011. Mutagenic and genotoxic assessment of atrazine-based herbicide to freshwater fish Channa punctatus (Bloch) using micronucleus test and single cell gel electrophoresis. Environ. Toxicol. Phar., 31 (2):314-322. http:// dx.doi.org/10.1016/j.etap.2010.12.001

RAMSDORF, W.A., FERRARO, M.V., OLIVEIRA-RIBEIRO, C.A., COSTA, J.R. \& CESTARI, M.M. 2009a Genotoxic evaluation of different doses of inorganic lead (PbII) in Hoplias malabaricus. Environ. Mon. Assess., 158 (1):77-85. http:// dx.doi.org/10.1007/s10661-008-0566-1

RAMSDORF, W.A., GUIMARAES, F.D.F., FERRARO, M.V.M., GABARDO, J., TRINDADE, E.D. \& CESTARI, M.M. $2009 \mathrm{~b}$. Establishment of experimental conditions for preserving samples of fish blood for analysis with both comet assay and flow cytometry. Mutat. Res./ Genetic Toxicol. Environ. Mutag., 673 (1):78-81. http://dx.doi.org/10.1016/j.mrgentox.2008.11.010

SALABERRIA, I., HANSEN, B.H., ASENSIO, V., OLSVIK, P.A., ANDERSEN, R.A. \& JENSSEN, B.M. 2009 Effects of atrazine on hepatic metabolism and endocrine homeostasis in rainbow trout (Oncorhynchus mykiss). Toxicol. Appl. Pharm., 234 (1):98106. http://dx.doi.org/10.1016/j.taap.2008.09.023

SELIM, H., 2003. Retention and runoff losses of atrazine and metribuzin in soil. J. Environ. Qual., 32, 1058-1071.

SPEIT, G. \& HARTMANN, A. 1999. The comet assay (single-cell gel test), a sensitive test for the detection of DNA damage and repair. In: Henderson, D.S. (ed) Methods in Molecular Biology: DNA repair protocols - eukaryotic systems. Human Press, Totowa, pp 203-211

TILLITT, D.E., PAPOUliAS, D.M., WHYTE, J.J., RICHTER, C.A. 2010. Atrazine reduces reproduction in fathead minnow (Pimephales promelas). Aquat. Toxicol., 99 (2):149-159. http:// dx.doi.org/10.1016/j.aquatox.2010.04.011

USEPA. 2006. Decision documents for Atrazine. Washington D.C., 20460.

VENTURA, B.D.C., DE ANGELIS, D.D.F. \& MARIN-MORALES, M.A. 2008.Mutagenic and genotoxic effects of the Atrazine herbicide in Oreochromis niloticus (Perciformes, Cichlidae) detected by the micronuclei test and the comet assay. Pestic. Biochem. Phys., 90 (1):42-51. http://dx.doi.org/10.1016/j. pestbp.2007.07.009

VRYZAS, Z., ALEXOUDIS, C., VASSILIOU, G., GALANIS, K. \& PAPADOPOULOU-MOURKIDOU, E. 2011. Determination and aquatic risk assessment of pesticide residues in riparian drainage canals in northeastern Greece. Ecotoxicol. Environ. Safe, 74 (2):174-181. http://dx.doi.org/10.1016/j.ecoenv.2010.04.011

XING, H., WANG, J., LI, J., FAN, Z., WANG, M. \& XU, S. 2010a. Effects of atrazine and chlorpyrifos on acetylcholinesterase and Carboxylesterase in brain and muscle of common carp. Environ. Toxicol. Pharm., 30 (1):26-30. http://dx.doi.org/10.1016/j. etap.2010.03.009

XING, H.J., HAN, Y., LI, S., WANG, J.T., WANG, X. \& XU, S.W. 2010b. Alterations in mRNA expression of acetylcholinesterase in brain and muscle of common carp exposed to atrazine and chlorpyrifos. Ecotoxicol. Environ. Safe, 73 (7):1666-1670. http://dx.doi.org/10.1016/j.ecoenv.2010.07.013 